\title{
A moralidade no mundo: o sumo bem e a filosofia da história kantiana
}

\author{
Bruno Nadai \\ Professor visitante de Filosofia na UFABC.
}

Resumo: Este artigo divide-se em duas seções. Na primeira, proponho uma leitura do conceito kantiano de sumo bem que busca mostrar o seu lugar sistemático no interior do sistema prático kantiano. Contrapondo-me a interpretações consagradas, sustento que 0 sumo bem, sem ferir a autonomia moral, permite a Kant tratar de problemas que tiveram de ser abstraídos quando da determinação do fundamento da moralidade. Em seguida, busco aproximar o conceito de sumo bem da noção de progresso moral contida na filosofia kantiana da história, discutindo a tese de que tal progresso pode ser lido como uma alternativa ao postulado da imortalidade da alma e a interpretação de que ele permite uma representação possível e mais concreta da via pela qual o mundo sensível pode ser aproximado da ideia de um mundo moral.

Palavras-chave: Kant; sumo bem; história; moralidade; mundo.
Abstract: This paper has two sections. At first, I present an approach to Kant's concept of the highest good that tries to show its systematic place within Kant's practical system. Against established interpretations, I sustain that the highest good does not hinder autonomy; instead, it allows Kant to deal with problems that were left aside when he was elaborating the grounding of morality. Then, I compare the concept of the highest good with the idea of moral progress in Kant's philosophy of history. In the light of this comparison, I discuss the thesis according to which this progress can be interpreted as an alternative to the postulate of soul immortality and the interpretation according to which moral historical progress allows a possible and more concrete representation of how the sensible world can come closer to the idea of a moral world.

Keywords: Kant; highest good; history; morality; world.

Como se sabe, o caráter formal do princípio moral kantiano decorre de que, para Kant,

a moral não necessita em geral de nenhum outro fundamento material de determinação do livre arbítrio, isto é, de nenbum fim, nem 
para reconhecer o que seja dever, nem ainda para impelir a que ele se leve a cabo; mas pode e até deve, quando se trata de dever, abstrair de todos os fins ${ }^{1}$.

Essa afirmação de A religião nos limites da simples razão retoma a seguinte e central tese da Primeira Seção da Fundamentação da metafísica dos costumes: é na forma da lei, e não em nenhum conteúdo material do querer, que se baseia o princípio supremo da moralidade. E, para que não reste dúvida quanto ao papel que cabe à lei moral, a Crítica da razão prática insiste que a mera representação da lei é o próprio e único fundamento de determinação de um arbítrio moralmente determinado.

A insistência de Kant no caráter formal da fundamentação da moralidade em um princípio que abstrai de todos os fins materiais da vontade, e que deve ser ao mesmo tempo fundamento de determinação e motivo <Triebfeder > da ação moral, contribuiu fortemente para que interpretações exclusivamente atentas aos aspectos de fundamentação do sistema de certo modo negligenciassem a maneira como o filósofo procura responder aos problemas relativos às condições de realização da moralidade no mundo. A recusa do papel sistemático do conceito de sumo bem é parte importante de interpretações como a de Lewis Beck², por exemplo.

No entanto, veremos que Kant jamais deixou de reconhecer que ninguém age senão com vistas à realização de um fim, isto é, que "sem qualquer relação de fim não pode ter lugar no ser humano nenhuma determinação da vontade ${ }^{\prime \prime 3}$. Ou seja, também para Kant o sujeito moral tem de perguntar-se não apenas se a lei moral é o fundamento de determinação de sua vontade, mas também sobre o sentido de sua ação. Daí aquela conhecida expressão do "Prefácio" da Religião, segundo a qual um arbítrio que não visa um objeto determinado sabe como, mas não para onde tem de agir ${ }^{4}$. Ou seja, para Kant, a determinação da vontade tem sim relação com a possibilidade de realização de algum

1. KANT. I. A religião nos limites da simples razão. In: Kants Gesammelte Scbriften. Herausgegeben von der Königlich Preussischen Akademie der Wissenschaft. Berlin: Walter de Gruyter, 1968. Vol. 6, pp. 13-14, grifo meu. As traduções em português utilizadas são referidas na bibliografia. Alterei-as quando julguei necessário

2. Cf. BECK, L. W. A Commentary on Kant's Critique of Practical Reason. Chicago: University of Chicago Press, 1963, pp. 244-245.

3. KANT, I. A religião nos limites da simples razão, vol. 06, p. 04

4. cf. Idem, ibidem. 
fim ou efeito no mundo, embora a representação deste efeito possível não possa ser o "fundamento de determinação do arbítrio" ou um "fim prévio no propósito" do agente, caso em que cairia por terra o fundamento mesmo da moralidade 5 . Kant, portanto, admite uma "referência necessária" da vontade moralmente determinada a um fim a ser alcançado, mas apenas como "consequência da determinação do arbítrio pela lei", não como fundamento desta determinação ${ }^{6}$.

A relação entre a vontade moralmente determinada e um fim a ser alcançado é desenvolvida por Kant em sua doutrina do sumo bem. $\mathrm{Na}$ Religião, o fim moral visado pela vontade moralmente determinada - chamado de "sumo bem no mundo" - é descrito como o "fim terminal" < Endzweck> da moral, isto é, como "um ponto de referência da união de todos os fins ${ }^{\prime \prime 7}$. Importa aqui ressaltar que a ideia da união de todos os fins do sujeito moral é identificada com um "mundo que ele [o sujeito moral], guiado pela razão prática, criaria se estivesse em seu poder" fazer o que o dever lhe ordena ${ }^{8}$.

No mesmo sentido dessa ideia de um mundo moral que é criação dos sujeitos práticos, a Crítica da razão pura caracteriza a ideia do sumo bem como um "mundo moral", isto é, "o mundo na medida em que está conforme as leis morais" ${ }^{\prime \prime}$. O mundo moral, diz Kant, "é uma simples ideia, embora prática, que pode e deve ter a sua influência no mundo sensível, para torná-lo, tanto quanto possível, conforme a essa ideia"10. Nos parágrafos finais da Crítica da faculdade do juízo, o sumo bem é descrito como a ideia da "existência de seres racionais sob leis morais"11. A lei moral nos vincula a esta ideia, nos obriga a nos empenharmos em realizá-la e nos leva a admiti-la como "possível pela liberdade"12.

A ideia do sumo bem, fim terminal da vontade determinada moralmente, pressupõe portanto um empenho do sujeito moral para

\footnotetext{
5. Idem, ibidem.

6. Idem, ibidem.

7. Idem, p. 05.

8. Idem, p. 05.

9. KANT, I. Crítica da razão pura, A 808/B 836.

10. Idem, A 808/B 836.

11. KANT, Crítica da faculdade de julgar. In: Kants Gesammelte Scbriften. Herausgegeben von der Königlich Preussischen Akademie der Wissenschaft. Berlin: Walter de Gruyter, 1968, vol. 05, p. 444.
}

12. Idem, vol. 05, p. 450 
a transformação do mundo sensível em um mundo moral. Lida dessa forma, a doutrina do sumo bem guarda semelhanças com a filosofia da história kantiana. Em textos como a Ideia de uma bistória universal de um ponto de vista cosmopolita, Sobre a expressão corrente e À Paz Perpétua, Kant apresenta a hipótese de que a história humana pode ser exposta como um progresso político-jurídico que pode levar a um desenvolvimento moral da humanidade ${ }^{13}$. E parece ser deste mesmo progresso moral que trata sua doutrina do sumo bem, na medida em que, como vimos, ela traz consigo a ideia de um empenho dos sujeitos práticos em fazer o mundo sensível aproximar-se da ideia de um mundo moral. Tendo isso em vista, procuraremos determinar mais precisamente quais vínculos podem ser efetivamente estabelecidos entre a filosofia da história e a doutrina do sumo bem, uma vez que não se encontram referências explícitas à filosofia da história nas passagens da obra kantiana onde a problemática do sumo bem é desenvolvida.

\section{O conceito de sumo bem}

A despeito de algumas variações consideráveis no papel sistemático que Kant atribui ao conceito de sumo bem ao longo de diferentes obras de sua filosofia prática, veremos que se mantém constante a concepção de que ele é o fim ou objeto da razão pura prática, que esta última nos põe a promoção ou realização do sumo bem como dever e que no conceito de sumo bem estão reunidos virtude (ação por dever) e felicidade. Nesta seção, desenvolverei de maneira breve o próprio conceito de sumo bem, chamando atenção para a principal mudança em seu lugar no interior do sistema. A determinação adequada do lugar sistemático do conceito de sumo bem me permitirá indicar também que a ideia de felicidade nele contida não põe em risco a autonomia da vontade. A partir daí, discutirei em que medida promover ou realizar o sumo bem no mundo é um dever distinto do dever moral, posto pelo imperativo categórico.

13. A afirmação de que a noção kantiana de progresso histórico compreende não só o progresso político-jurídico, mas também o progresso moral não é isenta de controvérsia. A respeito dessa questão, cf. KLEINGELD, P. Fortschritt und Vernunft: zur Geschichtsphilosopbie Kants. Würzburg: Königshausen \& Neumann, 1995. Cf. também NADAI, B. Progresso e moral na filosofia da bistória de Kant. Tese de Doutorado. São Paulo: FFLCH-USP, 2011. 
No interior da "Dialética da razão prática pura", o conceito de sumo bem é introduzido a partir de uma analogia com a busca da razão pura teórico-especulativa pela totalidade absoluta das condições (ou por um objeto incondicionado). Assim como a razão especulativa, para Kant, também a razão pura prática busca um incondicionado para o praticamente condicionado. $\mathrm{O}$ objeto condicionado da razão pura prática diz respeito às "inclinações" e a "uma carência natural" da vontade de um ser racional finito ${ }^{14}$. A totalidade incondicionada do objeto da razão prática pura corresponde, por sua vez, à ideia de um sumo bem.

Como se sabe, ficou estabelecido na "Analítica" da segunda Crítica que a vontade moral não pode encontrar seu fundamento de determinação em nenhum objeto - ela deve abstrair de toda matéria e objeto do querer. $\mathrm{O}$ objeto incondicionado a que a razão prática aspira não pode fazer as vezes de fundamento de determinação da vontade ${ }^{15}$. Este fundamento só pode residir na ideia de autodeterminação da vontade e, se Kant admite que a razão prática encontra o seu objeto incondicionado na ideia de sumo bem, tal objeto não pode ser fundamento, mas apenas consequência da determinação da vontade pela lei moral.

Sendo assim, a vontade moralmente determinada - à qual Kant se refere nesse contexto simplesmente como "virtude" - é compreendida no conceito de sumo bem como sua "condição suprema"16. Desse modo, nos termos da Crítica da razão prática, resolve-se a dificuldade de conciliar a necessidade racional de um fim ou objeto incondicionado (a ideia de sumo bem) com a concomitante impossibilidade de que este fim seja fundamento de determinação da vontade. Uma vez que a determinação moral da vontade está compreendida no conceito de sumo bem e o fundamento desta determinação reside apenas na mera representação da lei moral, o conceito de um sumo bem, enquanto objeto e fim da razão prática, é apenas indiretamente (isto é, apenas sob a condição da determinação da vontade pela lei) o fundamento de determinação da vontade.

14. KANT, I. Crítica da razão prática. In: Kants Gesammelte Schriften. Herausgegeben von der Königlich Preussischen Akademie der Wissenschaft. Berlin: Walter de Gruyter, 1968, vol. 05, p. 108.

15. Idem, ibidem.

16. Idem, vol. 05, p. 119. 
Diferentemente, a Crítica da razão pura ainda atribuía à ideia de sumo bem, e à ideia correlata de um mundo moral, o papel de motivo da ação moral ${ }^{17}$. Neste contexto, Kant também considera que a lei moral tem validade como fundamento objetivo de determinação da vontade, mas ainda não admite que ela possa ser capaz de motivar subjetivamente esta determinação. Por isso, ele afirma que apenas "um resultado que corresponda precisamente, seja nesta vida, seja numa outra, aos nossos fins supremos", isto é, à ideia de um mundo moral, pode oferecer um fundamento de determinação subjetivo suficiente para a vontade ${ }^{18}$. A partir da Crítica da razão prática, Kant passa a considerar que

o motivo da vontade humana $[\ldots]$ jamais pode ser algo diverso da lei moral, por conseguinte [...] o fundamento de determinação objetivo tem de ser sempre e unicamente o fundamento de determinação ao mesmo tempo subjetivamente suficiente da ação ${ }^{19}$.

Com isso, muda o papel sistemático que cabe à ideia de sumo bem: ele não pode mais contar como motivo da ação moral, pois o fundamento de determinação objetivo tem de ser, simultaneamente, o motivo subjetivo suficiente da determinação da vontade pela lei. Só assim a ação moral pode ser pensada como efetivamente autônoma. Como indicado acima, essa é a razão pela qual Kant é levado a considerar que o sumo bem só pode ser consequência da determinação da vontade pela lei. Ele não pode mais contar como motivo da determinação da vontade, papel que apenas a mera representação da lei pode desempenhar. Resta então ao sumo bem somente o papel de objeto incondicionado da razão pura prática, fim terminal da ação moral ${ }^{20}$.

A ideia de sumo bem, enquanto objeto total e incondicionado da razão pura prática, pressupõe, então, em primeiro lugar, a ideia de uma vontade moralmente determinada (virtude) como sua condição primeira. A virtude, por sua vez, (a vontade moralmente determinada)

17. Cf. KANT, I. Crítica da razão pura, A 813/B841.

18. Idem, A 813/B 841.

19. KANT, I. Crítica da razão prática, vol. 05, p. 72.

20. Para um desenvolvimento detalhado desta questão, cf. DÜSING, K. Das Problem des höchsten Gutes in Kants praktischer Philosophie. In: Kant-Studien 62, pp. 05-42. 
é a condição suprema e incondicionada do sumo bem (a que Kant chama de sumo bem supremum). Mas, visto que o sumo bem diz respeito à totalidade das condições de uma vontade finita, condições que se referem às inclinações e carências naturais de um ser racional finito, ele tem de incluir também a totalidade destas condições. A ideia de felicidade corresponde à ideia desta totalidade dos fins da inclinação ou das carências naturais. A felicidade é, assim, a condição condicionada do sumo bem. Por isso, Kant distingue o sumo bem supremum, a virtude, do sumo bem consumado, "sumo bem de um mundo possível", que diz respeito propriamente à conexão entre virtude e felicidade ${ }^{21}$. No sumo bem consumado, a "felicidade" é pensada como "distribuída na exata proporção da moralidade (enquanto valor da pessoa e do seu merecimento de ser feliz)" ${ }^{\prime \prime 22}$.

Entretanto, dada a necessidade de que a vontade moralmente determinada abstraia de todos os fins da inclinação, virtude e felicidade permanecem dois elementos completamente heterogêneos. Virtude e felicidade não são conceitos intercambiáveis e, se a ideia de sumo bem pressupõe uma conexão entre ambos, esta conexão não pode ser dada de maneira analítica. Se sua conexão não é analítica, ela tem então de ser sintética. Isto é, ou a virtude é causa da felicidade ou a felicidade é causa da virtude. Surge daí a "Antinomia da razão prática pura": por um lado, máximas da felicidade não são jamais máximas morais e a felicidade não pode conduzir à moralidade; por outro, não se pode esperar que a determinação da vontade pela lei moral possa necessariamente conduzir à felicidade, já que a conexão das causas e efeitos no mundo não se guia por nossas intenções morais, mas pelas leis naturais universais da natureza, alheias à nossa vontade ${ }^{23}$.

No entanto, como vimos, Kant toma o conceito de sumo bem como objeto e fim necessário da razão prática pura. Como ele afirma, "se o sumo bem for impossível segundo regras práticas, então também a lei moral, que ordena a promoção do mesmo, tem que ser fantasiosa e fundar-se sobre fins fictícios vazios, por conseguinte tem de ser em si falsa" ${ }^{\prime 24}$. Sendo assim, sob o risco de tomarmos como falsa a própria lei moral, condição suprema do sumo bem, é preciso solucionar esta

21. KANT, I. Crítica da razão prática, vol. 05, p. 110

22. Idem, vol. 05, p. 110.

23. Cf. Idem, vol. 05, p. 113-114.

24. Idem, vol. 5, p. 114. 
antinomia e mostrar de que modo se faz possível a promoção do sumo bem enquanto conexão de virtude e felicidade neste mundo. Dados os propósitos deste artigo, não discutirei os pormenores da solução da antinomia. Basta reter que, para solucioná-la, Kant se reporta à doutrina do duplo ponto de vista ${ }^{25}$ e mostra que, com a postulação da imortalidade da alma e da existência de Deus ${ }^{26}$, pode se pensar - ao menos como não impossível ou contraditório - que "a moralidade da intenção < Gesinnung $>$ tenha um nexo necessário, como causa, com a felicidade como efeito no mundo sensorial"127.

A admissão da ideia de felicidade como elemento condicionado da ideia de sumo bem é considerada por alguns intérpretes como uma introdução ilegítima de elementos empíricos e heterônomos na filosofia moral pura de Kant. Neste sentido, em seu comentário à Crítica da razão prática, Beck formula a objeção de que a aceitação da felicidade como objeto condicionado da ação moral representaria uma "renúncia da autonomia"28. Além disso, Beck se volta contra a ideia de que possa haver um dever de promover ou realizar o sumo bem que seja distinto do próprio dever moral contido no imperativo categórico. "Promover o sumo bem", afirma ele, é "simplesmente agir por respeito à lei, que eu já conheço [...]. É extremamente enganoso dizer que há um comando para buscar o sumo bem que seja diferente do comando para preencher as exigências do dever ${ }^{\prime \prime 2}$. Por tudo isso, Beck conclui que o conceito de sumo bem não pode ser considerado um "conceito prático" necessário da filosofia moral kantiana ${ }^{30}$.

A despeito da influência da interpretação de Beck, diferentes intérpretes têm procurado mostrar o papel despenhado pelo conceito de sumo bem no interior do sistema prático kantiano, ressaltando que ele não só tem lugar necessário na filosofia moral como também responde a questões de realização da moralidade que tiveram de ser deixadas de lado no momento inicial de fundamentação do princípio supremo da moralidade.

\footnotetext{
25. Cf. Idem, vol. 05, p. 114-115.

26. Cf. Idem, vol. 05, p. 119.

27. Idem, vol. 05, p. 115.

28. BECK, L. W. A Commentary on Kant's Critique of Practical Reason, pp. 244-245.

29. Idem, pp. 244-245.

30. Idem, p. 245.
} 
Klaus Düsing, por exemplo, busca mostrar que "o sumo bem da concepção tardia de Kant" - isto é, aquele da segundo Crítica em diante, que ressalta que o sumo bem não é motivo ou fundamento de determinação da vontade moral, mas seu fim e objeto necessário "pertence não à doutrina dos princípios da ética, mas a uma filosofia prática completa e desenvolvida, que investiga todas as capacidades fundamentais da consciência moral finita" ${ }^{\prime \prime}$. Segundo ele, o sumo bem, enquanto objeto necessário dos fins postos pela vontade finita, "é um esboço moral de nosso mundo, ideia diretriz de toda determinação e realização dos fins éticos individuais no mundo" ${ }^{\prime 32}$.

Partindo das contribuições de Düsing, Yirmiahu Yovel formula a ideia de que o conceito de sumo bem leva a filosofia prática kantiana a um segundo estágio, mais abrangente do que o inicial, meramente formal. Neste segundo estágio, entrariam em cena questões como a "realização da moralidade no reino da natureza, a totalização de trabalhos morais individuais em um novo sistema e, de modo geral, o remodelar das ordens empíricas dadas, de modo a que concordem com demandas morais ${ }^{\prime \prime 3}$. Extraindo as consequências desta interpretação para a filosofia da história, Yovel formula a tese de que o sumo bem seria "a ideia regulativa da história", na medida em que a "história" teria de ser entendida como "o processo no qual o sumo bem tem de ser realizado e no qual a ação livre e formativa da razão prática remodela o mundo dado em um mundo novo, um mundo moral"34.

A partir das formulações destes dois intérpretes, Harry Van der Linden propõe uma interpretação ainda mais ousada. Segundo ele, leituras formalistas e demasiado atentas à dimensão privada do juízo moral teriam negligenciado o aspecto social da ética kantiana. O papel sistemático do dever de promover o sumo bem no mundo, afirma ele, deveria levar à conclusão de que a ética kantiana é uma "ética social", em tudo oposta à "ética privada" a que a leitura da Fundamentação e da "Analítica" da segunda Crítica parecem primeiramente

31. DÜSING, K. Das Problem des Höchsten Gutes in Kants praktischer Philosophie, p.41.

32. Idem, ibidem.

33. YOVEL, Y. Kant and the Pbilosopby of History. New Jersey: Princeton University Press, 1980, p. 29. A respeito dos dois estágios da filosofia prática, cf. cap. 1.

34. Idem, p. 31. 
conduzir $^{35}$. Contrapondo-se à interpretação de Beck, que não vê no dever de promover o sumo bem senão o mesmo dever moral puramente formal contido nas formulações do imperativo categórico, Van der Linden afirma que "cada uma das formulações do imperativo categórico, tal como são explicadas na Fundamentação da metafísica dos costumes, exigem que aspiremos a uma sociedade moral, na qual os agentes humanos buscam fazer felizes uns aos outros ${ }^{1136}$. Nestes termos, as formulações do imperativo categórico já conteriam o conceito de sumo bem, o que autorizaria a conclusão de que a ética kantiana, mesmo quando trata da fundamentação da moral, seria uma ética social.

Não pretendo entrar no mérito da oposição entre "ética privada" e "ética social", nem discutir a ideia de que a filosofia moral kantiana, já no nível de sua fundamentação, seria uma ética social ${ }^{37}$. Tampouco debaterei a tese de Düsing, segundo a qual a doutrina do sumo bem conduziria a uma filosofia prática completa e desenvolvida, capaz de explicitar todas as capacidades fundamentais da consciência moral finita. Ao apontar para essas questões, quero apenas sugerir que a ideia de que há uma relação necessária entre a vontade moralmente determinada e a realização de um fim (introduzida por Kant em sua doutrina do sumo bem) parece, de fato, levar a uma filosofia prática mais abrangente do que aquela exposta nas obras de fundamentação. De qualquer modo, salta aos olhos que a contraposição de todos estes intérpretes à leitura de Beck concorda num ponto fundamental: Kant não se restringiu a formular uma filosofia moral formal, mas também se ocupou das condições de realização da moralidade.

Tendo isso em vista, farei breves considerações a respeito dos dois pontos da objeção de Beck ao papel sistemático do conceito de sumo bem. Em um primeiro momento, discutirei a tese de que a felicidade,

35. VAN DER LINDEN, H. Kantian Etbics and Socialism. Indianapolis: Hacket Publishing Company, 1988, p. 04.

36. Idem, p. 07.

37. Deixo também a cargo do leitor o juízo a respeito da tese de Yovel, segundo a qual a filosofia da história kantiana só ganha sentido no interior da filosofia crítica quando lida à luz do conceito de sumo bem, como se o dever de promover o sumo bem fosse a ideia regulativa da história. Noto apenas que o preço a pagar por esta interpretação é excluir a filosofia da história exposta por Kant em seus textos "populares" do quadro dessa ideia regulativa (cf. Kant's Pbilsopby of History, p. 127). 
como componente do sumo bem, representaria uma renuncia à autonomia do sujeito moral e ao fundamento supremo da moralidade. Em um segundo, me contraponho à ideia de que o dever de promover o sumo bem não se distingue do dever contido no imperativo categórico.

\section{O sumo bem e a felicidade}

Como dito acima, Beck sustenta que a felicidade como componente do objeto da razão pura prática representa uma renuncia à autonomia do sujeito moral. Esta interpretação apoia-se na compreensão do conceito de felicidade como recompensa a ser esperada pelo agente que se determina a agir moralmente. De fato, Beck assume que "o elemento da recompensa não é $[\ldots]$ a principal premissa para o argumento da imortalidade na segunda Crítica, mas", continua ele, "Kant não o omite do argumento seguinte sobre a existência de Deus ${ }^{\prime \prime 38}$. Isto é, de acordo com Beck, a existência de Deus seria postulada para garantir a ideia de que a felicidade possa ser pensada como a recompensa que o sujeito moral pode esperar de sua conduta virtuosa.

Explicitando a tese de Beck, Nathan Rotenstreich define a felicidade, enquanto condição condicionada do sumo bem, como o estado de ânimo decorrente da satisfação de "inclinações e expectativas pré-morais e amorais" do sujeito prático ${ }^{39}$. A partir desta concepção de felicidade, cuja obtenção seria assegurada pela postulação da existência de Deus, o autor conclui: "a pessoa moral será recompensada"40. Tudo se passaria como se, a contragosto, o sujeito se empenhasse em promover o sumo bem no mundo e esperasse, ao final, a recompensa de ver satisfeitas suas inclinações e carências naturais contrárias à moralidade, que tiveram de ser abstraídas quando da determinação de sua vontade.

No entanto, a interpretação do conceito de felicidade como estado de ânimo decorrente da satisfação de inclinações contrárias à moralidade, não parece ser corroborada por nenhuma passagem da "Dialética" da segunda Crítica ${ }^{41}$. De fato, ao longo da "Analítica", Kant

38. BECK, L. W. A Commentary on Kant's Critique of Practical Reason, p. 273.

39. ROTENSTREICH, N. Practice and Realisation. Studies in Kant's Moral Pbilosopby. Deen Hagg/Boston/London: Martinus Nijhoff, 1979, p. 146.

40. Idem, p. 146.

41. Na "Dialética", Kant define "felicidade" de maneira neutra em relação à moralidade: "Felicidade é o estado de um ser racional no mundo para o qual, 
se refere ao conceito de felicidade como o "conjunto" dos "princípios práticos materiais" de determinação da vontade ${ }^{42}$. Tais princípios visam "a sensação de agrado que o sujeito espera da efetividade do objeto" que determina sua vontade ${ }^{43}$. Este conceito de felicidade corresponde ao conceito de felicidade que Beck e Rotenstreich supõem estar incluído no conceito de sumo bem. E eles teriam razão em apontar para uma renúncia ao princípio da autonomia caso fosse este o conceito de felicidade que, na "Dialética", Kant toma como componente do sumo bem consumado. Pois, como vimos, na felicidade de que trata a "Analítica", princípios materiais relativos a carências naturais contrárias à moralidade, provenientes do amor de si, são postos como "fundamento de determinação" da vontade ${ }^{44}$. No entanto, o conceito de sumo bem consumado pressupõe não qualquer princípio material, mas a lei moral como fundamento de determinação da vontade. Portanto, é preciso distinguir os conceitos de felicidade da "Analítica" e da "Dialética da razão prática pura".

Como vimos acima, no início da "Dialética" da segunda Crítica, Kant reporta o "praticamente condicionado" (a felicidade) às "inclinações" e a "uma carência natural"45. Contudo, a felicidade possibilitada pelo sumo bem consumado parece dizer respeito à satisfação das carências naturais de um sujeito que se determina a agir moralmente e não à satisfação de carências contrárias à moralidade. As carências do sujeito que persegue o sumo bem dizem respeito à expectativa de sucesso de sua ação de transformar o mundo sensível em um mundo moral ${ }^{46}$. Segundo esta interpretação, a felicidade, como componente

no todo de sua existência, tudo se passa segundo seu desejo e vontade e depende, pois, da concordância da natureza com todo o seu fim, assim como com o fundamento de determinação essencial de sua vontade" (Crítica da razão prática, vol. 05, p. 124). Se o "fim" e o "fundamento de determinação" da vontade são morais, então pode-se pensar em uma "felicidade moral".

42. KANT, I. Crítica da razão prática, vol. 05, p. 22.

43. Idem, vol. 05, p. 22

44. Idem, ibidem.

45. Idem, vol. 05, p. 108.

46. Cf. KLEINGLED, P. Moral und Verwirklichung: zu einigen Themen in Kants Kritik der praktischen Vernunft und derem Zusammenhang mit seiner Geschichtsphilosophie. In: Zeitschrift für pbilosopbische Forscbung, 44. Frankfurt am Main: Vittorio Klostermann, 1990, pp. 425-441. 
do sumo bem, não é um estado decorrente da satisfação de inclinações contrárias à moralidade. A felicidade contida no sumo bem tem de ser entendida como relativa ao estado de ânimo decorrente do sucesso da ação que visa promover o sumo bem.

Todo ser racional finito tem carências naturais; e não pode ser diferente em relação ao o sujeito da ação moral. Mas a condição suprema da ideia de sumo bem, a determinação da vontade pela lei moral, requer que as carências do sujeito da ação de promover o sumo bem digam respeito à sua expectativa de criar um mundo moral. Sua felicidade é o estado de ânimo decorrente do sucesso desta empreitada. Neste contexto, a felicidade consiste na satisfação das carências de uma vontade moralmente determinada e distingue-se da felicidade pensada como satisfação das carências de uma vontade que tem no amor de si, ou noutros motivos patológicos, seu fundamento de determinação.

Por conseguinte, o estado de ânimo descrito por este conceito de felicidade corresponde à satisfação de uma carência bastante precisa, a saber, aquela expressa na expectativa de que a natureza concorde com nossos fins morais. Ou seja, o sujeito feliz aqui é aquele bem sucedido em sua tarefa de reordenar o mundo de tal forma que este passe a concordar com sua vontade, a qual, por sua vez, é uma vontade moralmente determinada. Por isso, Kant conclui o primeiro capítulo da "Dialética da razão prática pura" mostrando que, no conceito de sumo bem, o conceito de felicidade está subordinado à determinação moral da vontade e pressupõe o conceito de autonomia:

no conceito de sumo bem a lei moral já está compreendida como condição suprema [...] e a representação de sua existência possível mediante a nossa razão prática é ao mesmo tempo o fundamento de determinação da vontade pura; porque então a lei moral - já efetivamente incluída e pensada conjuntamente nesse conceito - e nenhum outro objeto determina a vontade segundo o princípio da autonomia ${ }^{47}$.

A primeira objeção de Beck ao conceito de sumo bem, segundo a qual a felicidade nele contida como condição determinada implicaria uma renúncia ao princípio da autonomia, é questionável. Tratarei agora da segunda objeção formulada pelo intérprete.

47. KANT, I. Crítica da razão prática, vol. 05, pp. 109-110. 


\section{O dever de promover o sumo bem}

Beck extrai a conclusão de que não pode haver um dever de promoção do sumo bem que se distinga do dever contido desde sempre no imperativo categórico do fato de que a lei moral é a condição suprema do conceito de sumo bem. Vimos que Kant corrige a concepção defendida inicialmente no "Cânone" da Crítica da razão pura, segundo a qual o sumo bem seria o motivo subjetivo de determinação da vontade. A partir da segunda Crítica, Kant passa a considerar que a lei moral tem de ser, ao mesmo tempo, fundamento objetivo $e$ motivo subjetivo de uma vontade moralmente determinada. Com isso, o sumo bem deixa de contar como motivo e passa a ser apenas objeto incondicionado da razão prática pura e fim terminal da ação do sujeito moral. Kant então esclarece que o fim visado pela razão prática pura é consequência e não fundamento de determinação da vontade, e que a lei moral é incluída no conceito de sumo bem como sua condição suprema.

Mas, então, será preciso dar razão a Beck? Isto é, terá ele razão em afirmar que o dever de promover o sumo bem não acrescenta nada ao dever contido no imperativo categórico? Vários intérpretes ${ }^{48}$ dirão que não. Penso ser preciso concordar com eles. Segundo Kant, em seres racionais finitos (tal como nós, humanos), a razão prática pura não se satisfaz apenas com a determinação do princípio supremo da moralidade. Ela carece também de um objeto incondicionado e põe um fim terminal para a ação moralmente determinada. Sendo assim, o dever contido no imperativo categórico e o dever de promover o sumo bem não podem ser intercambiáveis. Como afirma Kant, "a proposição 'faz do sumo bem possível no mundo o teu fim terminal' [...] é introduzida pela lei moral", mas por meio dela "a razão prática se estende para além desta última; tal é possível porque a lei se refere

48. Cf. ALLISON, H. The Gulf between Nature and Freedom and Nature's Guarantee of Perpetual Peace. In: Robinson, O (org) Proceedings of the Eighth International Kant Congres. Milwaukee: Marquette University Press, 1995, pp. 37-49; DÜSING, K. Das Problem des höchsten Gutes in Kants praktischer Philosophie; KLEINGELD, P. Fortscritt und Vernunft: Zur Geschichtsphilosopbie Kants, cap. 8 ; SILBER, J. Kant's Conception of the Highst Good as Immanent and Transcendent. In: Pbilosopbical Review vol. 68, n. 04, 1959, pp. 468-492; VAN DER LINDEN, H. Kantian Ethics and Socialism, cap. 1. 
à propriedade natural do homem de ter de pensar para todas as ações, além da lei, ainda um fim"49.

Mas no que propriamente se baseia a proposição "faz do sumo bem possível no mundo o teu fim terminal", enquanto proposição que se estende para além da lei moral e põe um fim moral para ação?

Como a citação acima indica, o dever de promover o sumo bem é introduzido pela própria lei moral. Afinal, o sumo bem tem na lei moral a sua condição suprema. Mas, se este dever é introduzido pela lei moral, ele, no entanto, não se confunde com ela, uma vez que o conceito de sumo bem contém mais elementos do que a lei moral, isto é, contém também a referência necessária a um fim ${ }^{50}$. O conceito de sumo bem pressupõe uma síntese entre o conceito de uma vontade moralmente determinada e o conceito de felicidade, entendida como a satisfação decorrente da ação de fazer o mundo sensível aproximar-se o máximo possível da ideia de um mundo moral. Portanto, o conceito de sumo bem é introduzido pela lei moral, mas não se esgota nela. Até porque a ideia de um fim da ação moral é necessariamente abstraída quando da determinação da vontade pela lei.

O sumo bem como fim terminal da vontade moralmente determinada é um mundo moral. E, como vimos, a conexão sintética entre a vontade moralmente determinada e a felicidade contida no conceito de sumo bem é de tal ordem que a primeira tem de ser pensada como causa da segunda, jamais o inverso. Ou seja, apenas a ação de um sujeito moralmente determinado pode promover o sumo bem, já que máximas da felicidade não podem produzir nenhuma virtude. Apenas a ação moral pode ser causa da felicidade, desde que, assim entende Kant, postule-se a existência de um autor do mundo, sábio e benevolente, capaz de assegurar que o curso da natureza possa vir a concordar com os fins da ação moral.

Portanto, se a lei moral é um dever incondicional, se o sumo bem como fim terminal da ação moral corresponde a um mundo moral e se apenas a ação moral pode produzir o sumo bem, então promover um mundo moral é também um dever incondicional. Dito noutros termos: o sumo bem é um fim da razão pura prática e corresponde à

49. KANT, I. A religião nos limites da simples razão, vol. 06, p. 07, nota.

50. Sigo aqui em linhas gerais o argumento de KLEINGELD, P. Vortschritt und Vernunft: Zur Geschicbtspbilosopbie Kants, pp. 139-143. 
ideia de um mundo moral, somente a ação de um sujeito que se determina pela lei moral pode promover um mundo moral $_{i}$ a lei moral comanda incondicionalmente, logo, a promoção do mundo moral é também comandada incondicionalmente.

A força normativa do dever de promover o sumo bem como mundo moral assenta, portanto, na mesma força normativa contida no dever posto pelo imperativo categórico. No entanto, isso não implica que os dois deveres sejam um e o mesmo, porque a lei moral não toma em consideração nenhum fim, enquanto o sumo bem é o fim terminal da ação moral. A promoção de um mundo moral é um fim necessário da razão pura prática, mas este fim só pode ser alcançado por uma vontade que se determina pela lei moral. Por isso, a força normativa do dever moral está contida no dever de promover o sumo bem, embora este último signifique uma ampliação do dever moral contido no imperativo categórico em direção à ideia da satisfação da carência de um objeto ou fim próprio da vontade de um ser racional finito.

Beck tem razão quando afirma que não pode haver outro princípio moral além do imperativo categórico: o dever de promover o sumo bem encontra no próprio imperativo categórico a sua força normativa. Mas isto não implica que o dever de promover o sumo bem não se distinga do dever contido no imperativo categórico. $\mathrm{O}$ que diferencia os dois deveres é que o dever de promover o sumo bem ordena ao sujeito moral também o seu empenho para realizar a ideia de um mundo moral, enquanto o imperativo categórico exige do sujeito apenas a concordância de suas máximas com a forma da lei moral. Esta ampliação de escopo da razão pura prática se explica pela carência de totalização ou pela carência de um objeto prático incondicionado da razão pura prática. Sem que o sujeito moral se pergunte pelo sentido ou pelo fim de sua ação, a possibilidade de realização de fins morais no mundo não pode ser pensada.

\section{O sumo bem e a filosofia da história}

O dever de promover o sumo bem no mundo se apresenta como o dever de promover um mundo moral. O dever de promover um mundo moral implica a noção de um empenho dos sujeitos práticos em aproximar o mundo sensível da ideia de um mundo moral. Neste sentido, a doutrina kantiana do sumo bem guarda semelhanças com a filosofia kantiana da história, em especial com aquela formulada em Sobre a expressão corrente, texto no qual Kant apresenta uma justificação 
da hipótese da história como progresso baseada no dever de promover o melhoramento moral da humanidade. Este dever se impõe como uma obrigação de agir sobre as sucessivas gerações de tal modo que elas possam, por si mesmas, aproximar-se progressivamente de seu melhoramento moral ${ }^{51}$. Assim, o possível resultado da ação ordenada por este dever parece coincidir com a ideia da promoção de um mundo moral.

No entanto, salta aos olhos que, nas passagens onde desenvolve a problemática do sumo bem, Kant não faz referências explícitas à filosofia da história. Portanto, buscarei confrontar brevemente a doutrina do sumo bem com a ideia de progresso moral contida na filosofia da história.

\section{O dever de atuar pelo melhoramento moral das futuras gerações e o postulado da imortalidade da alma}

A ideia de um melhoramento moral da humanidade, admitida como hipótese na filosofia da história kantiana, diz respeito à possibilidade de um aumento gradual, ao longo do tempo, das ações praticadas por dever. Segundo Kant, este melhoramento moral só se deixa pensar como possível numa progressão que se estende indefinidamente, resultado da ação dos indivíduos das sucessivas gerações que se põem a agir pelo dever de promover o melhoramento moral da posteridade ${ }^{52}$. Nestes termos, a filosofia da história oferece a ideia de um fim terminal da história, no qual a humanidade alcançaria sua destinação na Terra ${ }^{53}$. Portanto, a filosofia da história fornece a ideia de um momento futuro de realização da moralidade. Na Ideia de uma bistória universal, Kant se refere a este momento futuro hipotético como a transformação da sociedade em um "todo moral" ${ }^{54}$. Evidentemente, para que um tal todo social moral possa ser possível, é preciso que cada um dos seres humanos que o compõe sejam indivíduos virtuosos,

51. Cf. KANT, I. Sobre a expressão corrente: isso pode ser correto na teoria mas nada vale na prática. In: Kants Gesammelte Scbriften. Herausgegeben von der Königlich Preussischen Akademie der Wissenschaft. Berlin: Walter de Gruyter, 1968, vol. 08, p. 309.

52. Cf. Idem, vol. 08, p. 309.

53. Cf. KANT, I. Idéia de uma bistória universal de um ponto de vista cosmopolita. In: Kants Gesammelte Schriften. Herausgegeben von der Königlicb Preussischen Akademie der Wissenschaft. Berlin: Walter de Gruyter, 1968, vol. 08, p. 30.

54. Idem, vol. 21 
isto é, sejam seres humanos cuja vontade se conforma plenamente à moralidade. A ideia de um todo moral pressupõe uma totalidade de indivíduos virtuosos, cujas vontades são determinadas moralmente.

Neste sentido, é possível pensar uma aproximação entre a ideia de progresso moral histórico e o postulado da imortalidade da alma. Vimos que a possibilidade de promoção do sumo bem tem como condição suprema a plena conformidade da vontade à lei moral. A ideia desta plena conformidade é chamada de "santidade" da vontade ${ }^{55}$. Em princípio, no entanto, a santidade da vontade é impossível de ser alcançada por seres racionais finitos, cuja razão prática não é sempre suficientemente capaz de determinar a vontade. Para tornar possível a representação de uma vontade finita que se adéqua plenamente à lei moral, a razão pura prática postula a imortalidade da alma.

Segundo Kant, a ideia de santidade da vontade "somente pode ser encontrada em um progresso que avança ao infinito em direção àquela conformidade plena" da vontade à lei ${ }^{56}$. Na Crítica da razão prática, Kant considera que este progresso infinito somente é possível sob a pressuposição de que a existência do ser racional é perdurável ao infinito. Postulando a existência indefinida da alma ao longo do tempo, é possível pensar que o indivíduo purifica paulatinamente sua vontade da influência dos móbiles do amor de si, de tal modo que, em algum momento futuro, sua vontade passe a ser determinada exclusivamente pela lei moral. Sendo assim, Kant conclui que "o sumo bem é praticamente possível somente sob a pressuposição da imortalidade da alma; por conseguinte, esta, enquanto inseparavelmente vinculada à lei moral, é um postulado da razão prática pura" ${ }^{157}$.

No entanto, Kant poderia ter oferecido outra solução para o problema da possibilidade da condição suprema do sumo bem. Como ele mesmo afirma na Ideia de uma bistória universal, os indivíduos humanos são "todos mortais", mas a "espécie é imortal"58. A ideia de que a espécie humana é imortal apoia-se no fato de que as gerações sucedem-se umas às outras e que, por isso, o patrimônio cultural, civilizatório e relativo ao grau de esclarecimento que cada geração possui a respeito

55. KANT, I. Crítica da razão prática, vol. 05, p. 122.

56. Idem, p. 122.

57. Idem, p. 122.

58. KANT, I. Ideia de uma bistória universal de um ponto de vista cosmopolita, vol. 08, p. 20. 
do funcionamento do juízo prático pode e deve ser transmitido de uma geração a outra, por meio de processos educativos ${ }^{59}$. A possibilidade de transmissão ininterrupta deste, digamos assim, "legado espiritual" confere imortalidade à humanidade. A ideia de imortalidade da espécie humana está atrelada a esta noção de transmissão pedagógica das conquistas da cultura e, como vimos acima, o progresso moral de que Kant fala em Sobre a expressão corrente depende da atuação das sucessivas gerações segundo o dever de promover as condições para que a posteridade possa se fazer melhor de um ponto de vista moral.

Sendo assim, Kant poderia ter respondido ao problema da santidade da vontade recorrendo à ideia de imortalidade da espécie humana, sem que fosse necessário pressupor a imortalidade da alma individual. De fato, a ideia de imortalidade da espécie já se fazia presente na filosofia da história kantiana desde a primeira metade da década de 1780, antes portanto da formulação da antinomia da razão prática. Que ele não o tenha feito talvez se explique pelo fato de que a questão da condição de possibilidade do sumo bem busca satisfazer não apenas o problema prático de como fazer progredir a moralidade no mundo, mas também o problema teórico-especulativo do modo de acesso aos objetos tradicionais da metafísica clássica (no caso, do modo de acesso à ideia de imortalidade da alma $)^{60}$.

O postulado da imortalidade da alma resolve apenas a questão da possibilidade da condição suprema do sumo bem, mas para se pensar as condições de possibilidade do sumo bem completo ou consumado é preciso ainda considerar a questão da possibilidade da conexão entre virtude e felicidade. Motivo pelo qual nos voltaremos agora à relação entre a filosofia da história e a ideia de sumo bem como unidade sintética entre virtude e felicidade.

\section{O progresso moral na filosofia da história e a conexão entre virtude e felicidade}

A ideia de um sumo bem consumado, no qual a virtude é pensada como causa da felicidade, conduz ao postulado da existência de

59. Cf. Começo conjetural da bistória bumana, Kants Gesammelte Schriften. Herausgegeben von der Königlich Preussischen Akademie der Wissenschaft. Berlin: Walter de Gruyter, 1968, vol. 08, p. 118.

60. Cf. NADAI, B. Progresso e moral na filosofia da bistória de Kant, cap. 2. 
Deus. Como indiquei anteriormente, máximas da felicidade não podem ser causa da virtude. Do mesmo modo, máximas de virtude não garantem por si sós o alcance da felicidade, já que esta última diz respeito a um estado de ânimo que resulta do efeito das ações no mundo sensível, algo que escapa à nossa vontade. Mesmo que estas ações sejam moralmente motivadas, e que o conceito de felicidade compreendido no conceito de sumo bem diga respeito ao estado de ânimo decorrente do sucesso da ação moralmente motivada (como mostrei acima), ainda assim, o sucesso da ação que visa aproximar o mundo sensível da ideia de um mundo moral depende que as leis universais da natureza possam comportar nossos fins morais.

Apenas na medida em que postula a existência de um criador moral do mundo, a razão prática pode conceber a possibilidade de um acordo entre virtude e felicidade, entre a ação moralmente motivada e o curso da natureza. Mas este acordo não pode ser conhecido pelo sujeito moral, uma vez que diz respeito aos efeitos de suas ações no mundo sensível. E Kant não faz qualquer referência à ideia de um criador moral do mundo em nenhum de seus textos de filosofia da história. Neste sentido, o dever de promover o sumo bem e a ideia kantiana de progresso histórico não são coincidentes.

Além disso, tal como a entendo, a ideia kantiana de progresso histórico abrange tanto o progresso político quanto o progresso moral da humanidade. E é sabido que a ideia de justiça política, meta subalterna do progresso histórico, não diz respeito à felicidade ou bem estar do povo ${ }^{61}$. Do mesmo modo, a justificação da hipótese do progresso oferecida em Sobre a expressão corrente, baseada no dever de promover o melhoramento moral da humanidade, não faz qualquer referência à necessidade de ligação entre o progresso moral e a obtenção da felicidade.

No parágrafo da Crítica da faculdade do juízo onde retoma a concepção de história exposta na Ideia de uma bistória universal, Kant opõe explicitamente felicidade e cultura, mostrando que apenas esta última pode consistir no verdadeiro fim último da natureza ${ }^{62}$. Isto é, se a cultura (ou história) humana é um fim da natureza, ela não diz respeito à obtenção da felicidade. No entanto, fica evidente que o conceito de felicidade aí em jogo não é o conceito que compõe o sumo bem,

61. Cf. KANT, I. Sobre a expressão corrente, vol. 08, p. 302.

62. Cf. KANT, I. Crítica da faculdade de julgar, vol. 05, pp. 429-430. 
mas aquele mesmo conceito de felicidade da "Analítica" da segunda Crítica: "o conceito de felicidade não é tal que o homem possa abstraí-lo dos seus instintos e desse modo o retire da sua animalidade nele mesmo; pelo contrário, é a mera ideia de um estado, uma ideia à qual ele quer fazer seu estado adequado, sob condições simplesmente empíricas $^{\prime \prime 63}$. No entanto, na terceira Crítica, esse conceito de felicidade será suplantado pelo conceito de felicidade da "Dialética" da segunda Crítica - isto é, o conceito de felicidade incluído no conceito de sumo bem, cujos traços delineei acima - quando Kant retoma a problemática do sumo bem, no contexto da relação entre a prova moral da existência de Deus e o conceito de uma causa inteligente do mundo fornecido pela teleologia física. Ainda assim, nessas passagens, nenhuma vinculação explícita é estabelecida entre o dever de promover o sumo bem e a filosofia da história.

Entretanto, Kant não nega que o progresso histórico possa resultar num aumento da felicidade humana. "A natureza", diz ele,

quis que o homem tirasse inteiramente de si tudo o que ultrapassa a ordenação mecânica de sua existência e que não participasse de nenhuma felicidade ou perfeição senão daquela que ele próprio proporciona a si mesmo, livre do instinto, por meio da própria razão ${ }^{64}$.

Como se sabe, para Kant, ainda que seja um fim da natureza, o progresso histórico depende daquilo que o homem faz de si mesmo e ele não recusa que este fazer de si mesmo possa resultar não apenas na participação na perfeição - que a sequência da passagem citada indica ser uma perfeição moral, atrelada à boa vontade - mas também na felicidade.

A referência à ideia de que tal participação na felicidade será obtida "por meio da própria razão" e "livre do instinto" pode indicar que se trata aí do conceito de felicidade do sumo bem. Como vimos, este conceito é aquele próprio do sujeito que se determina a agir segundo o mandamento da razão pura prática, enquanto o conceito desenvolvido na "Analítica" da primeira Crítica diz respeito à satisfação dos fins da inclinação. Mas esta interpretação não é conclusiva, uma

63. Idem, vol. 05, p. 430.

64. KANT, I. Ideia de uma bistória universal de um ponto de vista cosmopolita, vol. 08, p. 19. 
vez que, como se sabe, a razão prática também pode ter um uso não propriamente puro e pôr-se a serviço da realização de fins da inclinação (como fica evidente nos imperativos hipotéticos). Não seria despropositado interpretar esta passagem como se a participação na felicidade, obtida por meio de um uso pragmático da razão, correspondesse à realização de fins da inclinação postos por imperativos hipotéticos.

Por um lado, se o conceito de felicidade em questão nesta passagem da Ideia de uma bistória universal corresponde ao conceito de felicidade da "Analítica", então se pode conjeturar que há um vínculo entre progresso histórico e felicidade, pois com o progresso técnico-científico (que Kant considera parte do progresso histórico), a humanidade pode esperar maior felicidade ao realizar seus fins da inclinação (ao menos todos aqueles ligados ao bem-estar). Por outro lado, se o conceito de felicidade corresponde, nesse contexto, ao conceito de felicidade contido no sumo bem, então se pode propor uma explicação do vínculo entre progresso histórico e felicidade nos moldes da explicação que ofereci acima para a questão do vínculo entre virtude e felicidade afirmado na doutrina do sumo bem: o progresso histórico é também um progresso moral e, se a felicidade corresponde ao estado de ânimo resultante da satisfação da carência de aproximar o mundo sensível da ideia de um mundo moral, então o sujeito do progresso histórico torna-se tanto mais feliz quanto mais progride a história.

Seja como for, Kant parece oscilar com relação ao vínculo entre progresso histórico e felicidade, ora afirmando ser "estranho" que o progresso leve à felicidade, ora afirmando que isso é "necessário":

permanece aqui sempre estranho [...] que somente as gerações posteriores devam ter a felicidade de habitar a obra que uma longa linhagem de antepassados (certamente sem esse propósito) edificou, sem mesmo poder participar da felicidade que preparou. E por enigmático que isto seja, é, entretanto, também necessário, quando se aceita que uma espécie animal deve ser dotada de razão e, como classe de seres racionais, todos mortais, mas cuja espécie é imortal, deve todavia atingir a plenitude do desenvolvimento de suas disposições ${ }^{65}$.

65. Idem, vol. 08, p. 20. 
Pode-se também formular uma outra interpretação sobre o nexo possível entre a filosofia da história e a doutrina do sumo bem por meio da aproximação entre o postulado da existência de Deus e a concepção teleológica de natureza (ou, simplesmente, Providência) própria da filosofia da história. Na doutrina do sumo bem, a existência de Deus é postulada para que seja possível pensar o acordo entre virtude e felicidade (entre a vontade moralmente determinada e o curso da natureza), enquanto na filosofia da história a ideia de que a natureza opera segundo fins é admitida hipoteticamente para justificar a hipótese da história como progresso. Esta interpretação é sustentada, por exemplo, por Pauline Kleingeld, que afirma que:

a concepção teleológica da história pode valer como uma representação possível que determina mais de perto o conteúdo da admissão mínima de conexão conforme a fins entre natureza e liberdade fundada por Deus e que torna mais preciso o caminho pelo qual o mundo moral se deixa aproximar gradualmente. Se a história empírica concorda com essa ideia de história, então a suposição abstrata daquela conexão conforme a fins [...] recebe a 'confirmação desejada ${ }^{\prime 66}$.

De fato, na Crítica da razão prática, Kant chega a sugerir que podemos "escolber" como representar o fundamento da possibilidade de um acordo entre virtude e felicidade ${ }^{67}$. Que essa representação leve ao postulado da existência de Deus, autor moral do mundo, é algo que se explica devido às limitações cognitivas própria dos seres racionais finitos e devido ao interesse prático que nossa razão associa inevitavelmente à realização de seu fim terminal ${ }^{68}$. Em certo sentido, portanto, podemos representar a possibilidade de realização do sumo bem no mundo recorrendo a outra forma de conformidade a fins que não aquela dada na ideia de um autor moral do mundo. Podemos, por exemplo, recorrer a uma representação teleológica da natureza.

O problema dessa interpretação, no entanto, reside em que, na Crítica da faculdade do juízo, do $\S 86$ em diante, Kant veta a possibilidade de uma passagem da teleologia física para a teologia moral (teologia que é fornecida pelo postulado da existência de Deus). Isso tem

66. KLEINGELD, P. Vortschritt und Vernunft: zur Geschicbtspbilosopbie Kants, p. 161.

67. KANT, I. Crítica da razão prática, vol. 05, p. 145.

68. Cf. Idem, vol. 05, p. 145. 
duas implicações para a questão aqui abordada. Por um lado, o conceito de uma natureza que opera segundo fins - ou mesmo o conceito de uma causa inteligente do mundo, capaz de produzir seres naturais organizados ou organizar a relação exterior entre os diferentes seres naturais - é um conceito completamente indeterminado e não pode levar à postulação da existência de um autor moral do mundo, exigida para se pensar o acordo em virtude e felicidade ${ }^{69}$. Por outro, como a teleologia da natureza (ou o conceito de uma causa inteligente do mundo capaz de operar segundo a representação de fins) não basta para pensar a necessidade de conexão entre a moralidade e o curso da natureza, a filosofia da história justifica apenas a bipótese de um progresso moral e não pressupõe que o curso empírico da história venha a corresponder a esta ideia. Aliás, não são poucas as passagens em que Kant afirma que o agregado de fenômenos das ações humanas mostra-se, "no seu conjunto, entretecido de tolice, capricho pueril e frequentemente também de maldade infantil e vandalismo ${ }^{1770}$.

O postulado da existência de Deus exige mais do que a ideia de uma teleologia da natureza pode oferecer. Esta última não é capaz de tornar representável o acordo entre a moralidade e o curso do mundo. Sendo assim, a filosofia da história não pode ser tomada como uma possível representação, mais precisa ou concreta, do acordo possível entre o mundo sensível e a ideia de um mundo moral. A existência de Deus é um postulado da razão pura prática, necessário para que a razão satisfaça sua carência de um objeto prático incondicionado. A teleologia da história é uma mera hipótese, justificada por razões teóricas e práticas, que serve para oferecer inteligibilidade ao agregado dos fenômenos da liberdade humana ou para permitir a representação da exequibilidade de certos deveres, políticos e morais, postos pela razão prática.

\section{Referências bibliográficas:}

ALLISON, H. The Gulf between Nature and Freedom and Nature's Guarantee of Perpetual Peace. In: Robinson, O (org) Proceedings of the Eighth International Kant Congres. Milwaukee: Marquette University Press, 1995, pp. 37-49.

69. KANT, I. Crítica da faculdade de julgar, vol. 04, p. 480.

70. KANT, I. Ideia de uma bistoria universal de um ponto de vista cosmopolita, vol. 08, p. 17. 
BECK, L. W. A Commentary on Kant's Critique of Practical Reason. Chicago: University of Chicago Press, 1963.

DÜSING, K. Das Problem des höchsten Gutes in Kants praktischer Philosophie. In: Kant-Studien 62, 1971, pp. 05-42.

KANT, I. Kants Werke: Akademie Textausgabe. Berlin: WalterdeGruyter \& Co, 1968.

A religião nos limites da simples razão. Trad. Artur Morão. Lisboa: Edições 70, 1992.

Sobre a expressão corrente: Isto pode ser correto na teoria, mas nada vale na prática. In: A paz perpétua e outros opúsculos. Trad. Artur Morão. Lisboa: Edições 70, 2002.

Começo conjetural da história humana. Trad. Bruno Nadai. In: Cadernos de filosofia alemã, 13. São Paulo: FFLCH-USP, 2009.

Crítica da razão prática. Trad. Valerio Rohden, São Paulo: Martins Fontes, 2002.

Crítica da razão pura. Trad. Manuela Pinto dos Santos e Alexandre Fradique Morujão. Lisboa: Ed. Fundação Calouste-Gulbenkian, 1989.

Crítica da faculdade do juízo, Trad. Valerio Rohden e António Marques. Rio de Janeiro: Forense Universitária, 1995.

Ideia de uma bistória universal de um ponto de vista cosmopolita. Org. Ricardo Ribeiro Terra. Trad. Rodrigo Naves e Ricardo R. Terra. São Paulo: Martins Fontes, 2003.

KLEINGELD, P. Fortscbritt und Vernunft: zur Geschichtsphilosopbie Kants. Würzburg: Königshausen \& Neumann, 1995.

Moral und Verwirklichung: zu einigen Themen in Kants Kritik der praktischen Vernunft und derem Zusammenhang mit seiner Geschichtsphilosophie. In: Zeitschrift für philosopbische Forscbung, 44. Frankfurt am Main: Vittorio Klostermann, 1990, pp. 425-441.

NADAI, B. Progresso e moral na filosofia da bistória de Kant. São Paulo: FFLCHUSP, Tese de Doutorado, 2011.

ROTENSTREICH, N. Practice and Realisation. Studies in Kant's Moral Pbilosophy. Deen Hagg/Boston/London: Martinus Nijhoff, 1979.

SILBER, J. Kant's Conception of the Highst Good as Immanent and Transcendent. In: Pbilosopbical Review, vol. 68, n. 04, 1959, pp. 468-492.

VAN DER LINDEN, H. Kantian Ethics and Socialism. Indianapolis: Hacket Publishing Company, 1988.

YOVEL, Y. Kant and the Philosopby of History. New Jersey: Princeton University Press, 1980. 
